Original article

\title{
Distinction between fill channels and abrasion furrows on ammonoid internal moulds
}

\author{
Distinction entre canaux de remplissage et sillons d'abrasion dans les \\ moules internes d'ammonoïdes
}

\section{Distinción entre canales de relleno y surcos de abrasión en los moldes internos de ammonites}

\author{
Sixto R. Fernández-López \\ Departamento de paleontología, facultad de ciencias geológicas (UCM) e instituto de geología económica (CSIC-UCM), 28040, Madrid, Spain
}

\begin{abstract}
Ammonoid sedimentary internal moulds can display grooves on the external or ventral region that have been formed by diverse taphonomic processes. In particular, draft-filling spiral channels and abrasion annular furrows are taphonomic structures useful as palaeoenvironmental indicators of turbulent waters and conditions of low rate of sedimentation, although they can show some common morphological properties that may lead to erroneous identifications. However, the morphological features, formation processes and palaeogeographic conditions in which the structures of these two types have been developed are very different. In consequence, it is important to keep in mind the distinctive characters of these taphonomic structures before using their occurrence in the palaeoenvironmental or palaeogeographic interpretations.
\end{abstract}

\section{Résumé}

Les moules internes formés par remplissage sédimentaire des coquilles d'ammonoïdes peuvent présenter des canaux et des sillons dans la région externe ou ventrale, qui ont été générés par divers processus taphonomiques. En particulier, les canaux spiraux de remplissage sédimentaire et les sillons annulaires d'abrasion sont des structures taphonomiques utiles comme indicateurs paléoenvironnementaux de régimes turbulents et de conditions de baisse de taux de sédimentation, bien qu'ils puissent présenter quelques propriétés morphologiques communes pouvant conduire à des identifications erronées. Néanmoins, tant les traits morphologiques que les processus de formation et les conditions paléogéographiques dans lesquelles se sont développées les structures de ces deux types sont très différentes. En conséquence, il est important de prendre en considération les caractères distinctifs de ces structures taphonomiques avant d'utiliser leur présence dans les interprétations paléoenvironnementales ou paléogéographiques.

\section{Resumen}

Los moldes internos de ammonites formados por relleno sedimentario de las conchas pueden presentar surcos y canales en la región externa o ventral que han sido generados por distintos procesos tafonómicos. En particular, los canales espirales de relleno sedimentario y los surcos anulares de abrasión son estructuras tafonómicas útiles como indicadores paleoambientales de regímenes turbulentos y condiciones de baja tasa de sedimentación, aunque pueden presentar algunas propiedades morfológicas comunes que pueden llevar a identificaciones erróneas. Sin embargo, tanto los rasgos morfológicos, como los procesos de formación y las condiciones paleogeográficas en las que se han desarrollado las estructuras de

E-mail address: sixto@geo.ucm.es. 


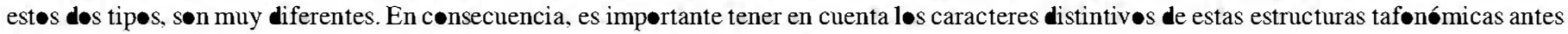

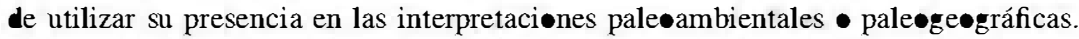

Keyw•rds: Ammonoidea; Jurassic; Taphonomy; Fossilization; Sedimentary palaeoenvironments; Palaeogeographic analysis

M॰ts clés : Ammonoidea ; Jurassique ; Taphonomie ; Fossilisation ; Paléoenvironnements sédimentaires ; Analyse paléogéographique

Palabras clave: Ammonoidea; Jurásico; Tafonomía; Fosilización; Paleoambientes sedimentarios; Análisis paleogeográfico

\section{Introduction}

Fill channels and abrasion furrows eccur on ammonoid internal moulds of complete shells as well as of incomplete phragmocones, and they show a number of properties in common. The features of søme fill channels developed on the external region of ammonøid sedimentary internal moulds have been investigated by Seilacher (1968, 1971, 1973); Mundles (1970); Duringer (1982); Hagdorn and Mundlos (1983) and Fernández-López (1997a). Similarly, the characteristics of søme abrasion furrows have been studied by Fernández-López (1985, 1995) and Fernández-López and Meléndez (1994, 1995).

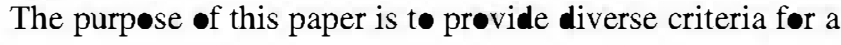
correct distinction between draft-filling spiral channels and abrasion annular furrows, taking inte account their relevance for palaeenvirømental and palae@gegraphic interpretations

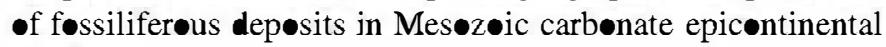
platforms.

\section{Fill channels}

According to data from the fossil record, søft parts, periostraca and siphuncular tubes of ammonoids showed increasing values of durability during biodegradation-decay processes (Seilacher et al., 1976, 1985; Hagdorn and Mundlos, 1983; Maeda and Seilacher, 1996; Fernández-López, 1997a, 1999, 2000a, 2000b). All these organic components of ammonoid remains could be biodegraded and destroyed in well-øxygenated marine waters, before the burial $\bullet$ the shells. In contrast, ammønøid shells maintaining søft parts in the bødy chamber and periostraca during early diagenesis should be

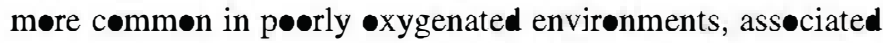
with more protected, restricted or deeper environmental conditions, as well as in environments of high rate of sedimentation and high rate of sediment accumulation.

Empty chambers of ammonøid shells could be filled with sedimentary particles before and after the burial. As a general rule, the sedimentary infill was introduced in the chambers by draft currents produce by outside turbulence (cf. Seilacher, 1963, 1966, 1971, 1973; Schindewølf, 1967; Mundles, 1970; Seilacher et al., 1976; Duringer, 1982; Hagdorn and Mundlos, 1983; Maeda and Seilacher, 1996; Fernández-López, 1997a, 2000b). The generation of draft hydraulic currents inside the shells would require that the chambers were communicated with the exterior by some orifice and the existence of a turbulent regime in the proximity of the shell. According to Bernøuilli's principle, if the outside turbulence could act on the orifice, a vacuum able to suck water with sedimentary particles in suspension int the shell could be produced in the phragmecone chambers. The stronger the turbulence, the greater the suction, and s- the sedimentary particles would be transported farther up the phragmocone. On the contrary, unbroken chambers keeping the siphuncular tubes or søt-parts still articulated would in turn continue being empty of sedimentary fill.

However, the sediment transported by draft currents towards the interior of the shell chambers is a load deposit, carrying particles in suspension; therefore, other extrinsic factors such as the size of the available sedimentary particles, the rate of sedimentation (calculated by dividing the thickness of sediment by the total time interval including the gaps) and the rate of sediment accumulation (estimated by dividing the thickness of sediment by the time interval of positive net sedimentation) may als• affect these filling processes of shells. In particular, the probability of shells to be filled with sediment will be inversely proportional to the rate of sedimentation and to the rate of sediment accumulation. Høllow ammonites (i.e., shells showing no sedimentary infill in the phragmecone) are dominant in expanded sections, formed in conditions of high rate of sedimentation and high rate of sediment accumulation, although they are usually compressed by gravitational diagenetic compaction (Fernández-López, 1997a, 1997b, 2000a, 2000b; Rebøulet et al., 2003). Expanded deposits formed by turbulence events under conditions of high rate of sediment accumulation, such as tempestites or turbidites, even in environments of low rate of sedimentation and associated

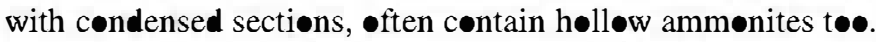
In contrast, ammonøids displaying phragmocones with complete and homøgeneøus sedimentary infill are commøn in condensed sections formed by condensed deposits, resulting from low values of both rate of sedimentation and low rate of sediment accumulation, in distal and deep marine environments (Fernández-López, 1997a, 1997b; Fernández-López et al., 1999, 2000, 2002; Fernández-López and Meléndez, 2004a, 2004b). Conversely, empty phragmocones showing no sedimentary infill (i.e., hølløw ammønites) or phragmøcones with heterogeneous sedimentary infill are common in condensed sections, of low rate of sedimentation, formed by expanded deposits of high rate of sediment accumulation in proximal and shallow marine environments (Fernández-López and Gómez, 1990; Gómez and Fernández-López, 1994; Fernández-López, 1997a, 1997b, 2000a, 2000b).

One $\bullet$ the clearest indications of the performance $\bullet$ intracameral draft streams on ammonøid shells, from the body chamber towards the apical chambers and through the septal foramens, is the occurrence of a sinuøus-shaped grøeve in, or a 
subcylindrical høllow conduct near $\bullet$, the outer surface $\bullet$ some sedimentary internal moulds. These superficial grooves and subsurface conducts pass through the septal necks along the mid-line of the ventral region on the phragmocone or connect the last septal foramen with the opening of the body chamber (Figs. 1-3). The existence of a sinuous groove on the outer surface of some internal moulds, which can describe a regular sinusoidal or crenulated pattern between any twe consecutive septa, provides a positive indication of the filling process of the camerae based on the principle of the through draft and the nature of the sedimentary filling mechanism in the ammonoid shells (Lehmann, 1976).

The mechanical stability of taphonomic elements, their azimuthal orientation and inclination, as well as the position and size of the orifices of the internal cavities are other intrinsic factors influencing the processes of sedimentary infilling of shells. Specimens bearing such fill channels are most commonly discoidal and planispiral moulds, platycones or cadycones, more rarely oxycones and never gløbular sphaerocones. These fill structures have been observed on internal moulds ranging from 15 to $250 \mathrm{~mm}$ diameter, and showing values of whorl thickness to diameter rati between 0.15 and 0.60 .

Furthermore, preservation of the produced fill channels requires early mineralization of the ammonoid internal moulds or of their sedimentary matrix, before compression by gravitational diagenetic compaction, in order to avoid diagenetic distortions. The proportion of clay must have influenced the maximum degree of conselidation attained by carbonate concretionary internal møulds of ammøn॰ids or their sedimentary matrix. In particular, if clay exceeds $2 \%$ in calcilutites, early cementation is inhibited and compaction will -ccur on subsequent løading (Gøldring and Kazmierczak, 1974). Consequently, complete or partial, concretionary internal moulds of ammonøids showing carbonate sedimentary infill and draft-filling spiral channel are indicative of subtidal environments, with turbulent regime and low rate of sedimentation conditions (due to winnowing action on the seafleor, sediment bypass or sediment starving). Distal and deep palaeønvirønments, in condensed deposits of low rate $\bullet$
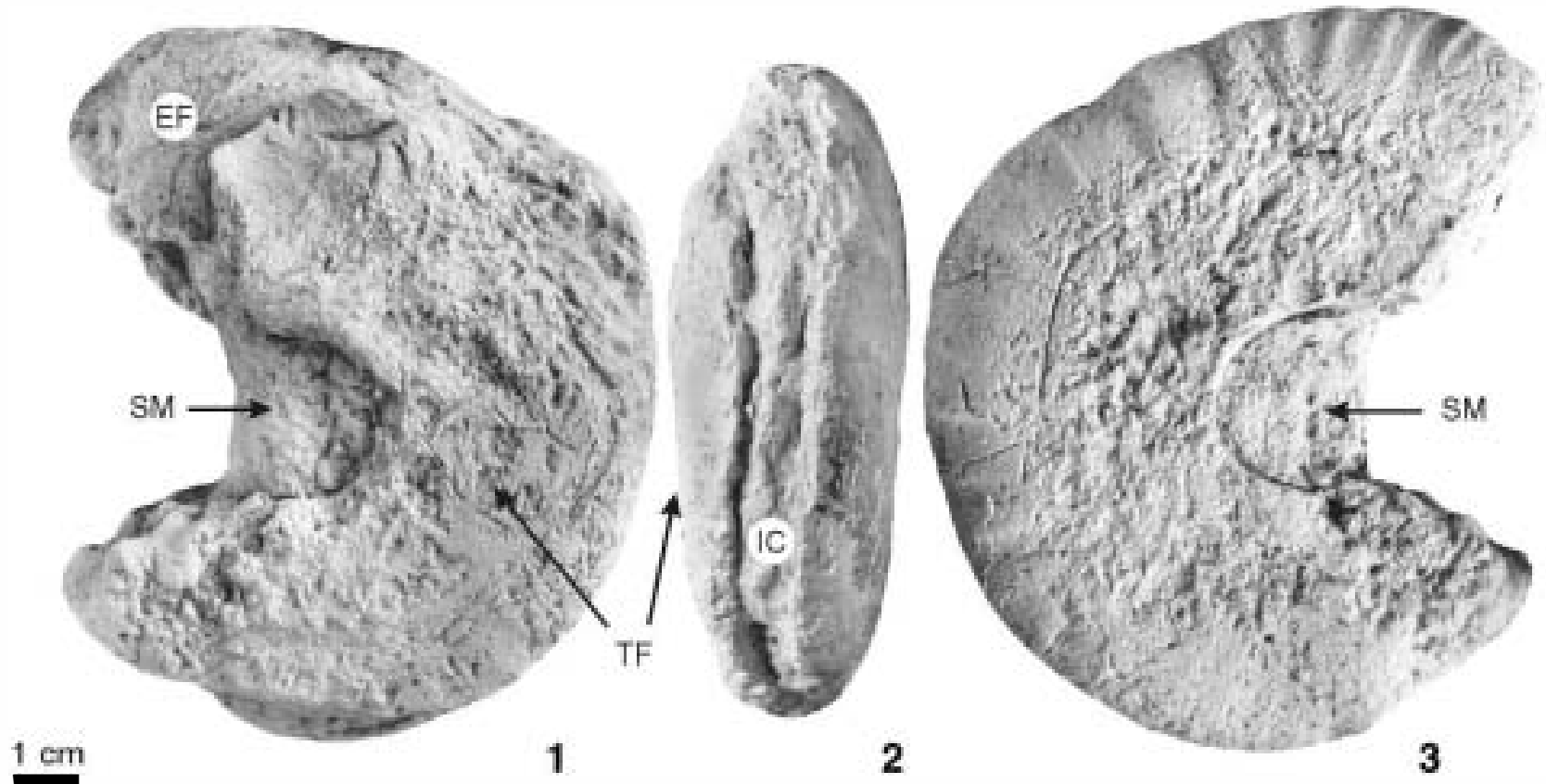

Fig. 1. Ptychøphylloceras sp. Callovian. Arroyofrio Bed, Domeño Formation (cf. Gómez and Fernández-López, 2004). Moscardón (Teruel). Coll. GM, M166/17. Lateral $(1,3)$ and ventral $(2)$ views. Internal mould of an incomplete phragmocone showing a sinuous fill channel (IC) in the external region, an ellipsoidal facet of abrasion (EF) in the last third of the preserved outer whorl and a wuncation facet (TF) in the right whorl side. The fill channel was formed by draft-current processes during resedimentation of the shell on the seafloor, before initial burial. The ellipsoidal facet and the trumcation facet were due to abrasion processes during ulterior reelaboration (i.e., exhumation and displacement before final burial) of the concretionary internal mould. The narrow and relatively deep infill channel displays sharp and prominent borders, and has even smaller width in some of the most superficial portions of the internal mould. Inner whorls or nucleus of the phragmocone (diameter less than $50 \mathrm{~mm}$ ) are not preserved, due to destruction of the hollow camerae during reelaboration. The volume of the nucleus was occupie by sedimentary matrix (SM) during final burial. Specimens figured here and in subsequent figures are whitene with magnesium oxide prior to photography.

Fig. 1. Ptychøphylloceras sp. Callovien. Couche Arroyofrio, Formation Domeño (cf. Gómez et Fernández-López, 2004). Moscardón (Teruel). Coll. GM, M166/17. Vues latérales $(\mathbf{1}, \mathbf{3})$ et ventrale (2). Moule interne d' un phragmocône incomplet, avec un canal sinueux de remplissage sédimentaire (IC) dans la région ventrale ou externe, une facette ellipsoïale 'abrasion (EF) dans le demier tiers de spire conservé et une facette de roncature (TF) dans le flanc droit. Le canal deremplissage a été forné par la circulation de l'eau à travers le phragmocône pendant des processus de resédimentation de la coquille sur le fond marin, avant l'enfouissement initial. La facette ellipsoïdale et la facette de concature ont été formées à la suite des processus abrasion ultérieurs du moule interne, à l'état de concrétion calcaire, pendant la rélaboration (i.e., exhumation et déplacement avant l'enfouissement final). Le canal sinueux de remplissage sédimentaire mon des bordes aigus et proéminent ; il est éroit et relavivement profond, et il est même plus éroit dans certaines portions plus superficielles du moule interne. Les tours internes ou nucleus du phragmocône (diamètreinférieur à $50 \mathrm{~mm}$ ) ne sont pas conservés, par destruction des chambres vides et sans remplissage sédimentaires pendant la réélaboration. Le volume du nucleus a été occupé par la matrice sédimentaire (SM) pendant l'enfouissement final. Les spécimens de cette figure et des suivantes ont été blanchis à la fumée de magnésium. 


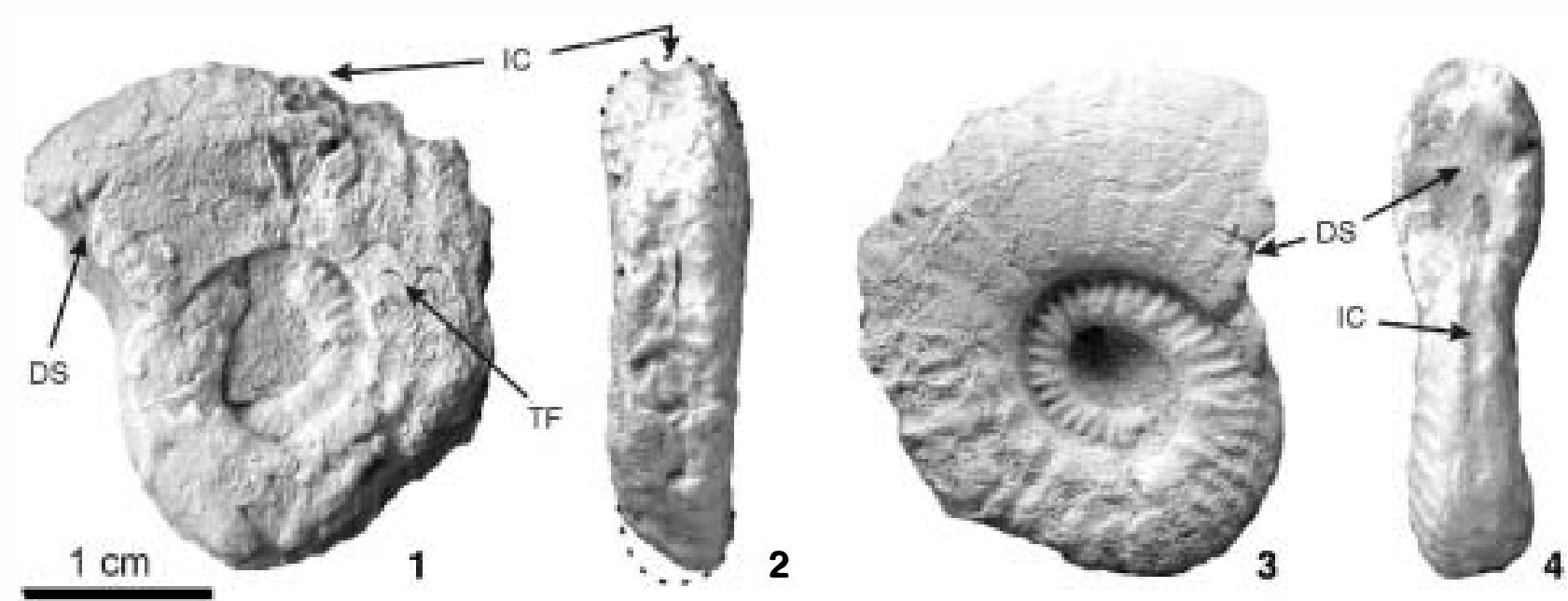

Fig. 2. Sonninia sp. Lower Bajocian. El Pedregal Fonnation (cf. Gómez and Fernández-López, 2044). Moscardón (Teruel). Coll. SRFL, M00/1. Lateral (1, 3), venual (2) and oral (4) views. Internal mould of an incomplete pbragmocone, showing a discontinuous fill channel (IC) in the external region, a trumcation facet (TF) in the right flank, and a disariculation surface (DS) at the end of the preserved outer whorl. Inner whorls of the phragmocone (diameter less than $6 \mathrm{~mm}$ ) are not preserved, by

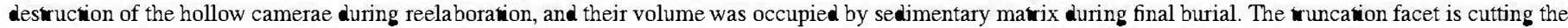
septa of the phragmocone. The disarticulation surface, developed along the boundary between sedimentary inflls of contiguous chambers, represents a structural discontinuity with the sedimentary matrix.

Fig. 2. Sonninia sp. Bajocien inférieur. Fonnation El Pedregal (cf. Gómez et Fernández-López, 2004). Moscardón (Teruel). Coll. SRFL, M00/1. Vues latérales (1, 3) ven rale (2) et orale (4). Moule interne d'un phragmocône incomplet, avec un canal discontinu de remplissage sédimentaire (IC) dans la région externe, une facette de woncature (TF) dans le flanc droit, et une surface de désariculation (DS) dans la parie terninale de la spire conservée. Les tours internes du phragmocône (diamè inférieur à $6 \mathrm{~mm}$ ) ne sont pas conservés, par des cuction des chambres vides sans remplissage sédimentaires pendant la rélaboration, et leur volume a été occupé par la marice sédimentaire pendant l'enfouissement final. La facette de troncature coupe les cloisons du phragmocône. La surface de désariculation, développée à la limite des remplissages sédimentaires des chambres voisines, représente une discontinuité stucturale avec la matrice sédimentaire.

sedimentation and low rate of sediment accumulation, would favour the develøpment and preservation of complete and hømøgeneous concretionary internal moulds of ammonøids showing draft-filling spiral channel and evidence of early mineralization. Conversely, proximal and shallow palaeenvironments, in expanded deposits of low rate of sedimentation but high rate of sediment accumulation, were favourable for develøpment and preservation of partial and heterøgeneøus concretionary internal moulds of ammonøids showing draftfilling spiral channel and evidence of early mineralization.

Nevertheless, the input of sedimentary particles int the shell cavities by draft-current processes was not the only filling
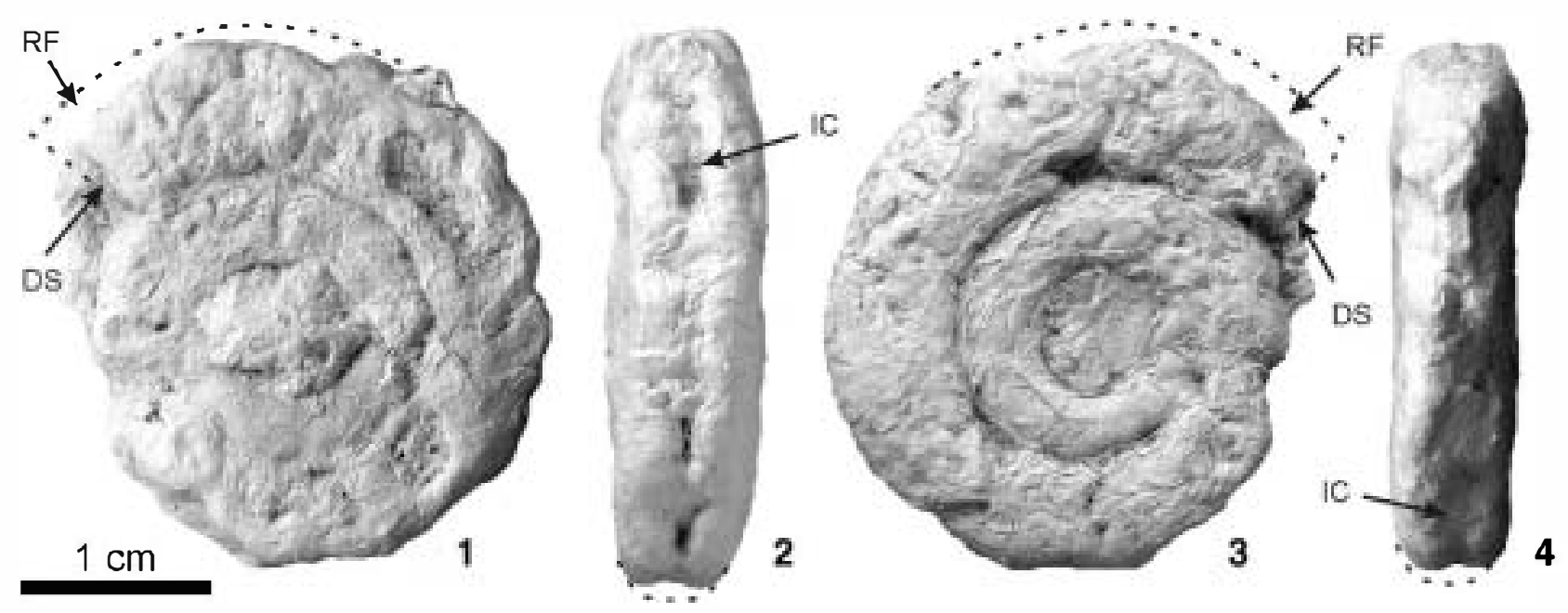

Fig. 3. Nannolytoceras sp., Toarcian. Top of the Zegrí Fonnation (cf. Sandoval and Checa, 2002; Caracuel et al., 2004). Cerro dela Cruz, La Romana (Alicante). Coll SRFL, CCo/l. Lateral $(\mathbf{1}, \mathbf{3})$, ventral (2) and oral (4) views. Iron-crust coated internal mould of an incomplete phragmocone, showing a discontinuous fill channel (IC) in the external region, as well as a disariculation surface (DS) in the terminal part of the preserved outer whorl, and a roll facet (RF) preferentially develope on the most prominent porion.

Fig. 3. Nannolytoceras sp., Toarcien. Toit de la Formation Zegrí (cf. Sandoval et Checa, 2002 ; Caracuel et al., 2004). Cerro dela Cruz, La Romana (Alicante). Coll SRFL, CCoo/1. Vues latérales $(\mathbf{1}, \mathbf{3})$ ventrale $(\mathbf{2})$ et orale $(\mathbf{4})$. Moule interne d'un phragmocône incomplet, avec encroûtements ferrugineux, que montre un canal discontinu de remplissage sédimentaire (IC) dans la région externe, ainsi qu'une surface de dés ariculation (DS) en position terminale et une facette de roulement (RF) préférentellement développée dans la parie la plus proéminente et tenninale des tours de spire conservés. 
mechanism giving rise to the formation of sedimentary internal moulds of ammonøid shells. The input of sedimentary particles inside the ammonoid shells could als happen by gravitational infiltration and bioturbation, as regards the occurrence of lithoclasts of centimetric size, as well as bioturbation textures and structures, in some internal moulds of ammonøids (Fig. 4; Henderson and McNamara, 1985; Fernández-López, 1997a).

\section{Abrasion furrows}

Abrasion or the mechanical wearing away of taphonomic elements preserved in marine environments is usually due to the impact on them of particles transported by the water or to the friction among the own taphonomic elements that are moved. In both cases, the external surface of taphon॰mic elements can be polished, and its positive reliefs can be worn away and even -bliterated. Nevertheless, taphonomic elements can be abraded only in a portion of their surface and acquire a waste facet (Müller, 1979; Brett and Baird, 1986; Brett, 1990). Truncation facets were formed when the taphonomic elements were fixed or anchored to the substratum and exposed to the action of søme abrasive agent. Under such conditions, a unidirectional current will produce a single facet; but several truncation or anchorage facets can be formed in the same taphonomic element, by changes in the direction of the currents or in the position of the abraded element. In contrast, roll or rounding facets tend to be developed on the most prominent superficial reliefs of the taphonomic elements, when they stay loose on the substrate, free of sedimentary marix, and subjected to the action of abrasive agents. Unlike truncation facets, roll facets tend to increase the degree of roundness and sphericity of the taphonomic elements.
Under the action of bottom currents in subtidal environments, internal moulds of ammonøids would tend to be abraded on one side and develop truncation facets (Figs. 1, 2 and 4)). Under the action of wave (oscillatory) currents in shallow subtidal environments, however, concretionary moulds would tend to overturn and develop roll facets (Fig. 3). Abrasion annular furrows and abrasion ellipsoidal facets (Fig. 5) were developed on free-rotating internal moulds, subjected t• directional water currents.

The origin of abrasion annular furrows and ellipsøidal facets carved on the internal moulds of ammonøids is explained by the action of directional, non-oscillatory currents, under extremely shallow bathymetric conditions (Fernández-López and Meléndez, 1994, 1995). Once exhumed and free of sedimentary matrix, and settled on a uniform and conselidated substrate, the reelaborated, concretionary internal moulds should be able to rotate and reorient. Reelaborated moulds having the centre of gravity far apart from the geometric centre and localized in the last third of the last preserved whorl, will tend to reorient the last portion of the outer whorl upstream, this portion hence being differentially abraded. An ellipsøidal facet would be first developed in the last portion of the outer whorl, and then the worn area would progress along the venter to carve a whole annular furrow. The water layer should be similar in thickness to the concretionary mould, so the ornamentation is preserved on the upper side of the mould. Specimens bearing such abrasion structures are platycone and cadycone moulds, and never gløbular sphaerocones or -xycones. These abrasion structures have only been observed on internal moulds showing a rati of whorl thickness to diameter between 0.35 and $\mathbf{0 . 6 0}$, and ranging in diameter between 50 and $250 \mathrm{~mm}$.
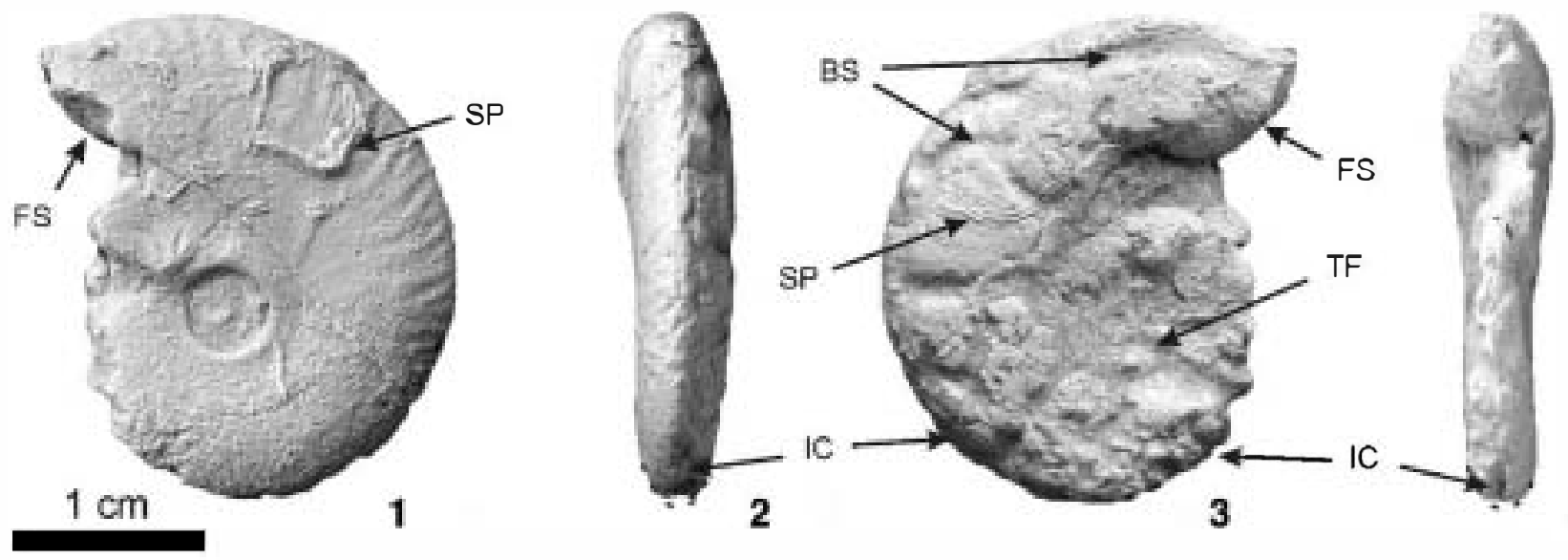

Fig.4. Bradfordia sp. Lower Bajocian. Rebolledo dela Torre (Burgos; cf. Pujalte et al., 1988; Robles et al., 1989). Coll. SRFL, 3RE 1 /1. Lateral (1, 3), venual (2) and oral (4) views. Internal mould of an incomplete phragmocone showing a discontinuous fill channel (IC) in the external region, a trmcation facet (TF) capping bioturbation suctures (BS) in the left flank, diverse remains of encrusting organisms (serpulids, SP), and a fracture surface (FS) at the end of the preserved outer whorl that represents a suctural disconinuity with the sedimentary mavix. The bioturbation swuctures were forned in a soft sedimentary infill of the shell, before early carbonate cementation and abrasion of the internal mould associated with reelaboration processes.

Fig. 4. Bradfordia sp. Bajocien inférieur. Rebolledo de la Torre (Burgos; cf. Pujalte et al., 1988 ; Robles et al., 1989). Coll. SRFL, 3RE00/1. Vues latérales (1, 3) ven rale (2) et orale (4). Moule interne d'un phragmocône incomplet, présentant un canal discontinu de remplissage sédimentaire (IC) dans la région externe, une facette de roncature (TF) que coupe des traces de bioturbation (BS) dans le flanc gauche, divers restes d'organismes encroûtants (serpules, SP) et une surface de fracture (FS) dans la partie tenninale de spire conservée qui représente une discontinuité structurale avec la matrice sédimentaire. Les structures de bioturbation ont été formées dans le remplissage sédimentaire de la coquille, quand il était encore en état mou, avant la cémentation carbonatée précoce et l'abrasion du moule interne associé à des processus de réélaboration. 

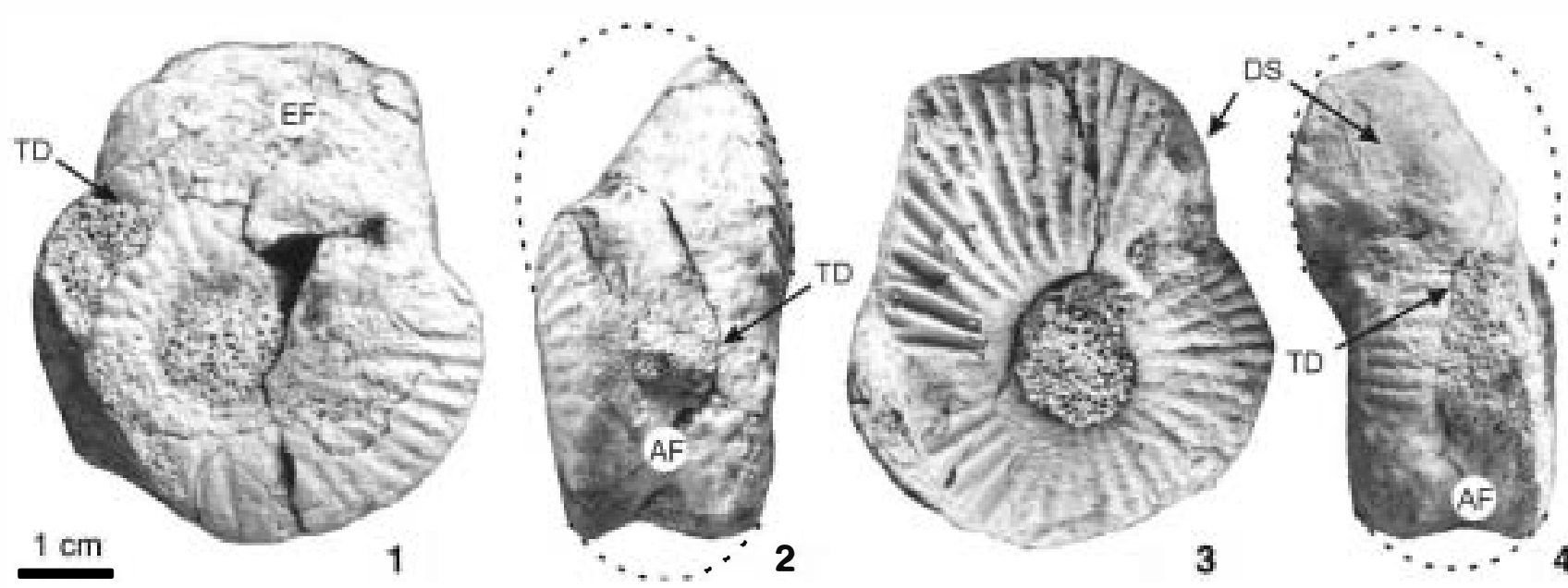

Fig. 5. Macrocephalites sp. Lower Callovian. Arroyofrio Bed, Domeño Fonnation (cf. Gómez and Fernández-López, 2004). Moscardón (Teruel). Coll. SRFL, $3 \mathrm{M} 166 / 4$. Lateral $(\mathbf{1}, \mathbf{3})$ ven $\mathrm{ral}(\mathbf{2})$ and oral $(\mathbf{4})$ views. Internal mould of an incomplete phragmocone showing an abrasion ellipsoidal facet (EF) on the last third of preserved outer whorl, an abrasion annular furrow (AF) on the whole venter and a disariculation surface (DS) at the end of the preserved outer whorl. The abrasion annular furrow is wide and shallow and shows rounded edges. Note the structural disconinuity (TD) between the micritic sedimentary infill and the oolitic sedimentary matrix, associated with abrasion surfaces and iron-crusts coating on the internal mould.

Fig. 5. Macrocephalites sp. Callovien inférieur. Couche Arroyofrio, Formation Domeño (cf. Gómez et Fernández-López, 2004). Moscardón (Teruel). Coll. SRFL, $3 \mathrm{Ml66/4}$. Vues latérales $(\mathbf{1}, \mathbf{3})$ ven rale (2) et orale (4). Mouleinterne d'un phragmocône incomplet, avec une facette ellipsoïdale d'abrasion (EF) dans le derniertiers de spire conservé, un sillon annulaire d'abrasion $(\mathrm{AF})$ dans la région ventrale et unesurface de désarticulation (DS) dans la partie tenninale de la spire conservée. Le sillon annulaire d'abrasion mon des bordes arrondis ; il est large et peu profond. Notez la discontinuité structurale (SD) en re le remplissage sédimentaire micritique et la matrice oolitique, associée à la présence des surfaces d'abrasion et des encroûtements ferrugineux dans le moule interne.

Early cemented or concretionary internal moulds of ammonøids bearing abrasion annular furrows are common in Jurassic carbonate rocks, within shallow epicontinental platforms deposits. They are usually found in condensed sections, formed by expanded sediments, and asseciated with sedimentary discontinuities and indurate surfaces, ranging frøm firmgrøunds t• hardgrounds (Fernández-López, 1985, 1995, 1997a, 1997b, 2000a, 2000b; Aurell et al., 1994, 2004; Fernández-López et al., 1996; Ramaj• and Meléndez, 1996; Meléndez et al., 2002). Fr॰m a palaeenvirømental pøint of view, abrasion annular furrows are useful as indicators of turbulent waters, high energy environments, and low rate of sedimentation. Frøm a palaengegraphic pøint $\bullet$ view, these abrasion structures are indicative $\bullet$ f extremely shallow bathymeric conditions, intertidal and peritidal environments being the most favourable.

\section{Distinction between draft-filling channels and abrasion furrows}

Draft-filling channels $\bullet$ the shells and abrasion furrows $\bullet$ the sedimentary internal moulds may display similar properties, such as preferential development on the external region of sedimentary internal moulds. However, they differ in morph logical characters, mechanisms, palaeøenvironments and palaenge graphic conditions of formation.

Draft-filling channels of the shells display the following characteristic features:

- They can be either superficial grøoves and subsurface conducts and are preserved on sedimentary internal moulds, passing through the septal orifices of the phragmocone or
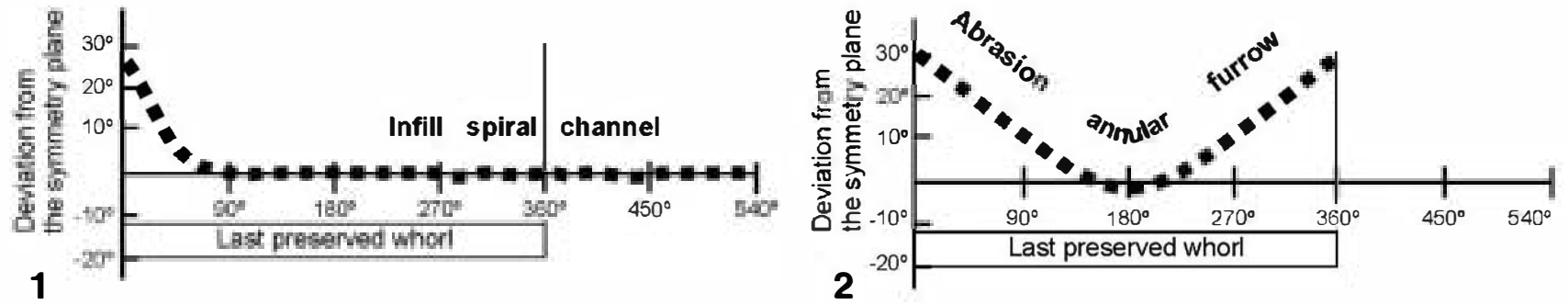

Fig. 6. Diagram showing the deviation from the symmery plane of the draft-filling spiral channels (1) and the abrasion annular furrows (2) developed on ammonoid internal moulds.

Fig. 6. Schéma de déviation par rapport au plan de symétrie des canaux spiraux eremplissage (1) et des sillons annulaires abrasion (2) développés dans les moules internes d'ammonoïdes. 
connecting the last septal foramen with the opening of the body chamber;

- they tend to display a spiral shape (Fig. 6(1));

- they can reach the inner whorls, surpassing $360^{\circ}$ in length, being conditioned by the spiral geometric form of the shell wall;

- they are located near the sagittal plane of the shell in the phragmocone, conditioned by the sagittal position of consecutive septal foramens; however, they can become asymmeric (deviation greater than $30^{\circ}$ from the symmetry plane) attaining a lateral position from the last septal foramen to the aperture;

- they show sharp and prominent borders, developed by accretion of fill sediments inside the chambers of the phragmocones, although they can display gentle edges in the body chambers;

- they are usually narrow and deep, showing their maximum depth in any point of the last preserved whorl;

- they tend to disappear irregularly, sømetimes diminishing in depth towards the apical chambers.

In contrast, abrasion furrows are develøped on concretionary internal moulds and display the following characteristic features:

- they are superficial grooves carved on the sedimentary internal moulds, cutting the septa of the phragmecone aløng the ventral region;

- they tend to display a ring shape (Fig. 6(2));

- they are restricted to the last preserved outer whorl, not surpassing $360^{\circ}$ in length;

- they are only developed on the ventral region, not on the flanks. However, they move away from the sagittal line in the last and the first quarter of the preserved outer whorl (between 0-90' and $270-360^{\circ}$ respectively); nevertheless, deviation with respect to the sagittal plane of the shell is less than $30^{\circ}$, maintaining a ventral position in the last third part of the last preserved whorl (where the shell reaches higher width values, be it the body chamber or the phragmocone);

- they show rounded borders, developed by abrasion of external surfaces of the sedimentary infill of the chambers;

- they are usually wide and shallow, showing their maximum depth in the last third of the preserved outer whorl;

- they tend to disappear gradually, diminishing in depth and becoming progressively shallower towards the diametrically -pposed point to that of the end of the last preserved whorl.

In addition to the morpholøgical differences, these taphenomic structures were formed by separate and independent processes. Draft-filling spiral channels were developed during resedimentation processes (i.e., displacement of the shells on the seafloor before initial burial), whereas abrasion annular furrows were developed during taphonømic reworking or reelaboration processes (i.e., exhumation and displacement on the seafloor of early cemented or concretionary internal moulds, before final burial in younger or contemporaneous deposits).

The sedimentary infill of ammonoid internal moulds bearing abrasion annular furrows is petrographically discontinuøus with the fabric of the enclosing sedimentary rock. Abrasion ellipsøidal facets and abrasion annular furrows cut the fabric of the internal moulds and have a counterpart impression in the sedimentary matrix around the fossil. In contrast, the sedimentary infill of ammonoid internal moulds bearing draft-filling spiral channels can be petrographically continuous or discontinuous with the fabric of the sedimentary matrix. Similarly, they can display or not a counterpart impression in the enclosing rock. On the one hand, reelaborated internal moulds bearing a draft-filling channel display a counterpart impression in the enclosing rock and are petrographically discontinuous with the fabric of the sedimentary matix. On the -ther hand, internal moulds of resedimented shells bearing a draft-filling channel do not display a counterpart impression in the enclosing rock and are petrographically continuous with the fabric of the sedimentary matrix.

From a palaeøenvironmental point of view, draft-filling spiral channels and abrasion annular furrows are taphonømic structures useful as indicators of turbulent regimes and conditions of low rate of sedimentation in marine subtidal environments, associated with condensed sections. From a palae ge graphic pøint of view, draft-filling spiral channels on complete and homogeneous sedimentary internal moulds were formed in conditions of low rate of sediment accumulation, under distal and deep bathymetric conditions. Conversely, draft-filling spiral channels on partial or heterøeneous sedimentary internal moulds were formed in conditions of low rate of sedimentation but high rate of sediment accumulation, under proximal and shallow bathymetric conditions. In contrast, abrasion annular furrows were produced under extremely shallow bathymetric conditions, intertidal and peritidal environments being the most favourable.

\section{Conclusions}

Draft-filling spiral channels and abrasion annular furrows, preferentially developed on the external region of ammonoid sedimentary internal moulds, can be distinguished by morphøløgical and genetic criteria.

Draft-filling spiral channels are (sub-)superficially developed, passing thrøugh the septal foramens of the phragmøcone or connecting the last septal foramen with the opening of the body chamber; they are relatively narrow and deep, showing sharp edges; they can occur either on reelaborated internal moulds petrographically discontinuous with the fabric of the sedimentary matix, and displaying a counterpart impression in the enclosing rock, or on resedimented elements petrographically continuous with the fabric of the sedimentary matrix, without a coumterpart impression in the enclosing rock. In contrast, abrasion annular furrows are superficially develøped, cutting the septa of the phragmocone; they are relatively wide and shallow, showing rounded edges; they occur on internal moulds petrographically discontinuous with the fabric of the sedimentary matrix; and they display a counterpart impression in the enclosing rock.

Both types of taphonomic structures were formed in marine environments, under turbulent regimes and low rate of 
sedimentation conditions, before final burial. Draft-filling spiral channels were formed during resedimentation processes, associated with complete and homogeneous sedimentary internal moulds in distal and deep environments, and partial -r heterøgeneous sedimentary internal moulds in proximal and shallow environments. Abrasion annular furrows were formed during taphonomic reworking or reelaboration processes under extremely shallow bathymetric conditions, in intertidal and peritidal environments.

\section{Acknowledgements}

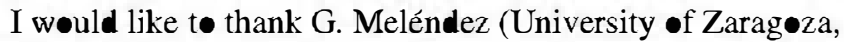
Spain) for his constructive comments and suggestions on the manuscript. This work is a contribution to the Project CGL2004-0694/BTE (MEC-CSIC).

\section{References}

Aurell, M., Bádenas, B., Meléndez, G., Bello, J., Bordonaba, A.P., Ipas, J., Ramajo, J., 2004. El Jurásico Superior al Sur de Zaragoza: estratigrafía secuencial y paleontología. In: Colombo Piñol, F., Liesa Carrera, C.L., Meléndez Hevia, G., Pocoví Juan, A., Sancho Marcén, C., Soria de Miguel, A.R. (Eds.), Geoguías, 1. Itinerarios Geológicos por Aragón, pp. 33-61.

Aurell, M., Fernández-López, S., Meléndez, G., 1994. The Middle-Upper Jurassic oolitic ironstone level (Iberian Chain, Spain): eustatic implications. In: Cariou, E., Hantzpergue, P. (Eds.), 3ème Symposium International de Stratigraphie du Jurassique. Poitiers, France 22-29 septembre 1991. Geobios MS 17, pp. 549-561.

Brett, C.E., 1990. Destuctive taphonomic processes and skeletal durability. In: Briggs, D.E.G., Crowther, P.R. (Eds.), Paleobiology, a Synthesis. Blackwell, Oxford, pp. 223-226.

Brett, C.E., Baird, G.C., 1986. Comparative taphonomy: a key to palaeoenvironmental interpretation based on fossil preservation. Palaios 1, 207-227.

Caracuel, J., Fernández-López, S.R., Tent-Manclús, J.E., Yébenes, A., 2004. Itinerario paleontológico por el Cerro de la Cruz (Sierra del Reclot). In: Alfaro, P., Andreu, J.M., Estévez, A., Tent-Manclús, J.E., Yébenes, A. (Eds.), Geología de Alicante. Universida de Alicante, Alicante, pp. $245-260$.

Duringer, Ph., 1982. Les remplissages sédimentaires des coquilles de céphalopodes wiasiques. Mécanismes et intérêt paléoécologique. Geobios 15, $125-145$.

Fernández-López, S., 1985. Criterios elementales de reelaboración tafonómica en ammonites de la Cordillera Ibérica. Acta Geológica Hispánica 19, $105-116$.

Fernández-López, S., 1995. Taphonomie et interprétation des paléoenvironnements. In: Gayet, M., Courinat, B. (Eds.), First European Palaeontological Congress, Lyon July 7-9, 1993. Geobios MS 18, pp. 137-154.

Fernández-López, S., 1997a. Ammonites, clinos tafonómicos y ambientes sedimentarios. Revista Española de Paleontología 12, 102-128.

Fernández-López, S., 1997b. Ammonites, taphonomic cycles and stratigraphic cycles in carbonate epicontinental platforms. Cuadernos de Geología Ibérica 23, 95-136.

Fernández-López, S., 1999. Tafonomía y Fosilización. In: Meléndez, B. (Ed.), Tratado de Paleontología. Consejo Superior de Investigaciones Científicas, Madrid, pp. 51-107.

Fernández-López, S., 2000a. Ammonite taphocycles in carbonate epicontinental platforms. In: Hall, R.L., Smith, P.L. (Eds.), Advances in Jurassic Research 2000. GeoResearch Forum 6, pp. 293-300.

Fernández-López, S.R., 2000b. Temas de Tafonomía. Departamento Paleontología, Universidad Complutense de Madrid.

Fernández-López, S.R., Aurell, M., García Joral, F., Gómez, JJ., Henriques, M.H.P., Marúnez, G., Meléndez, G., Suárez Vega, L.C., 1996. El Jurásico Medio de la Cuenca Catalana: unidades litoestratigráficas y elementos paleogeográficos. Revista Española de Paleontología, n` extraordinario, 122-139.

Femández-López, S.R., Duarte, L.V., Henriques, M.H.P., 1999. Reelaborated ammonites as indicator of condensed deposits from deep marine environments. Case study from Lower Pliensbachian limestones of Portugal. In: Rocha, R.B., Silva, C.M., Caetano, P.S., Kullberg, J.C. (Eds.), Links between fossils assemblages and sedimentary cycles and sequences. Workshop European Palaeontological Association, Lisboa, pp. 42-46.

Fernández-López, S.R., Duarte, L.V., Henriques, M.H.P., 2000. Ammonites from lumpy limestones (Lower Pliensbachian, Portugal). Taphonomic analysis and palaeoenvironmental implications. Revista Sociedad Geológica de España 13, 3-15

Fernández-López, S.R., Gómez, J.J., 1990. Facies aalenienses y bajocienses, con evidencias de emersión y carstificación, en el sector central de la Cuenca Ibérica. Implicaciones paleogeográficas. Cuadernos de Geología Ibérica 14, 67-111.

Fernández-López, S.R., Henriques, M.H.P., Duarte, L.V., 2002. Taphonomy of ammonite condense associations. Jurassic examples from carbonate platforms of Iberia. Abhandlungen der Geologischen Bundesanstalt 57, 423-430.

Fernández-López, S.R., Meléndez, G., 1994. Abrasion surfaces on internal moulds of ammonites as palaeobathymetric indicators. Palaeogeography, Palaeoclimatology, Palaeoecology 110, 29-42.

Fernández-López, S.R., Meléndez, G., 1995. Taphonomic gradients in Middle Jurassic ammonites of the Iberian Range (Spain). In: Gayet, M., Courtinat, B. (Eds.), First European Palaeontological Congress, Lyon, July 7-9, 1993. Geobios MS 18, pp. 155-165.

Fernández-López, S.R., Meléndez, G., 204a. Fossilization of ammonites and sedimentary events in deep environments of carbonate platform (highest Middle to lowest Upper Oxfordian, Iberian Range, Spain). Rivista Italiana di Paleontologia e Stratigrafia 11•, 219-230.

Fernández-López, S.R., Meléndez, G., 2004b. Taphonomic features of ammonite associations develope in deep carbonate platform environments (Oxfordian, Iberian range, Spain). In: Pena dos Reis, R., Callapez, P., Dinis, P. (Eds.), 23r IAS Meening of sedimentology, Abswacts book, Coimbra, p. 113.

Goldring, R., Kazmierczak, J., 1974. Ecological succession in intrafornational hardground fornation. Palaeontology 17, 949-962.

Gómez, JJ., Fernández-López, S., 1994. Condensation processes in shallow platfonns. Sedimentary Geology $92,147-159$.

Gómez, J.J., Fernández-López, S.R., 2004. Las unidades litoeswatigráficas del Jurásico Medio de la Cordillera Ibérica. Geogaceta 35, 91-94.

Hagdorn, H., Mundlos, R., 1983. Aspekte der Taphonomie von MuschelkalkCephalopoden. Teil 1: Siphozerfall und Füllmechanismus. Neues Jabrbuch für Geologie und Paläontologie. Abhandlungen 166, 369-403.

Henderson, R.A., McNamara, K.J., 1985. Taphonomy and ichnology of cephalopod shells in a Maastrich chalk from Westem Australia. Lethaia 18, $305-322$.

Lebmann, U., 1976. Ammoniten: Ibr Leben und ibre Umwelt. Enke, Stuttgart. Maeda, H., Seilacher, A., 1996. Ammonoid taphonomy. In: Landman, N.H., Tanabe, K., Davis, R.A. (Eds.), Ammonoid Paleobiology. Plenum Press, New York, pp. 543-578.

Meléndez, G., Bello, J., Ramajo, J., Ziani, H., 2002. The Callovian-Oxfordian ammonite succession in the NE Iberian Chain revisited: taphonomic gradients and palaeogeography. In: De Renzi, M., Pardo Alonso, M.V., Belinchón, M., Peñalver, E., Montoya, P., Márquez-Aliaga, A. (Eds.), Current Topics on Taphonomy and Fossilization. Ajuntament de Valencia, Valencia, pp. 407-418.

Muiller, A.H., 1979. Fossilization (Taphonomy). In: Robinson, R.A., Teichert, C. (Eds.), Treatise on Invertebrate Paleontology. Part A. In roduction. Geological Society of America and University of Kansas, Boulder, Colorado, pp. A2-A78.

Mundlos, R., 1970. Wohnkammerfilllung bei Ceratitengehäusen. Neues Jahrbuch für Mineralogie, Geologie und Paläontologie, Monatshefte 1970, 18-27.

Pujalte, V., Robles, S., Valles, J.C., 1988. El Jurásico marino delas zonas de alto sedimentario del borde SW de la cuenca Vasco-Cantábrica (Rebolledo de la Torre, Palencia). Ciencias de la Tierra 11, 85-93. 
Ramajo, J., Meléndez, G., 1996. El límite Calloviense-Oxfordiense en Ricla (Zaragoza). Análisis sedimentológico y tafonómico de una sucesión condensada rica en ammonoideos. In: Meléndez Hevia, G., Blasco Sancho, M_F., Pérez Urresti, I. (Eds.), II Reunión de Tafonomía y Fosilización. Institución 'Fernando El Católico', Zaragoza, pp. 337-345.

Reboulet, S., Mattioli, E., Pittet, B., Baudin, F., Olivero, D., Proux, O., 2003. Ammonoid and nannoplankton abundance in Valanginian (early Cretaceous) limestone-marl successions from the southeast France Basin: carbonate dilution or productivity? Palaeogeography, Palaeoclimatology, Palaeoecology 201, 113-139.

Robles, S., Pujalte, V., Valles, J.C., 1989. Los sistemas sedimentarios del Jurásico de la parte occidental de la cuenca Vasco-Cantábrica. Cuadernos de Geología Ibérica 13, 185-198.

Sandoval, J., Checa, A., 2002. Taphonomy of cephalopod concentrations in the Jurassic of the Subbetic (Southem Spain). In: De Renzi, M., Pardo Alonso, M.V., Belinchón, M., Peñalver, E., Montoya, P., Márquez-Aliaga, A. (Eds.), Current Topics on Taphonomy and Fossilization. Ajuntament de Valencia, Valencia, pp. 223-230.

Schindewolf, O.H., 1967. Analyse eines Amoniten-Gehäuses. Akademie der Wissenschaften und der Literatur in Mainz, Abhandlungen der mathematisch-naturwissenschaftlichen Klasse 1967, 135-188.
Seilacher, A., 1963. Umlagerung und Rolltransport von Cephaloponden-Gehäusen. Neues Jahrbuch für Mineralogie, Geologie und Paläontologie, Monatshefte 1963, 593-615.

Seilacher, A., 1966. Lobenlibellen und füllstruktur bei Ceratiten. Neues Jahrbuch für Mineralogie, Geologie und Paläontologie. Abhandlungen 125, 480-488

Seilacher, A., 1968. Sedimentationsprozesse in Ammonitengehäusen. Akademie der Wissenschaften und der Literatur in Mainz, Abhandlungen der mathematisch-naturwissenschaftlichen Klasse 1967, 9, 191-203.

Seilacher, A., 1971. Preservational history of ceratite shells. Palaeontology 14, 16-21.

Seilacher, A., 1973. Biostratinomy: The sedimentology of biologically standardized particles. In: Ginsburg, R.N. (Ed.), Evolving concepts in Sedimentology. John Hopkins University Press, Baltimore, pp. 159-177.

Seilacher, A., Andalib, F., Dietl, G., Gocht, H., 1976. Preservational history of compressed Jurassic ammonites from southem Germany. Neues Jahrbuch für Geologie und Palãontologie. Abhandlungen 152, 307-356.

Seilacher, A., Reif, W.E., Westphal, F., 1985. Sedimentological, ecological and temporal patterns of fossil Lagerstãtten. Philosophical Transactions of the Royal Society of London B 311, 5-23. 